\title{
Role of heterotrophic protists in first feeding by cod (Gadus morhua) larvae
}

\author{
Julia L. Overton ${ }^{1,3}$, Stefan Meyer ${ }^{2}$, Josianne G. Støttrup ${ }^{1}$, Myron A. Peck ${ }^{2, *}$ \\ ${ }^{1}$ Section for Coastal Ecology, National Institute for Aquatic Resources, The Technical University of Denmark, \\ Charlottenlund Castle, 2920 Charlottenlund, Denmark \\ ${ }^{2}$ Institute for Hydrobiology and Fisheries Science, University of Hamburg, Olbersweg 24, 22767 Hamburg, Germany \\ ${ }^{3}$ Present address: AquaPri Danmark A/S, Lergårdvej 2, 6040 Egtved, Denmark
}

\begin{abstract}
The present study evaluated whether the presence of autotrophic phytoplankton and/or heterotrophic dinoflagellates (Oxyrrhis marina) influenced first-feeding success and early larval growth and development of Baltic cod Gadus morhua L. Newly hatched cod larvae were maintained in salt water ('clear water', CW), greened water using Nannochloropsis sp. (NA) or a combination of Nannochloropsis sp. and $O$. marina (NO) from 2 to $11 \mathrm{~d}$ post-hatch. On each day, larvae from each group were placed into feeding tanks and provided potential prey (nauplii of the calanoid copepod Acartia tonsa). Feeding performance was measured both as the percentage incidence of feeding and gut fullness index. The onset of first feeding, point of no return and the magnitude of feeding were derived from the feeding incidence. The study clearly demonstrated precocious, exogenous feeding by cod larvae in the presence of Nannochloropsis sp. and $O$. marina by 1.2 and $2.2 \mathrm{~d}\left(10^{\circ} \mathrm{C}\right)$, respectively. Gut fullness was also significantly improved in the presence of both phytoplankton and protists over the entire window of opportunity (defined as the period between onset of first feeding and point of no return). However, the nutritional capacity of these unicellular organisms was not sufficient to alter the somatic growth characteristics in NA and NO groups relative to starving yolk-sac larvae maintained in only salt water (CW group). These findings expand the current understanding of the degree of interaction between fish larvae and unicellular plankton communities and indicate a lack of nutritional benefits from feeding on components of the pelagic microbial loop but a clear benefit in terms of 'priming' first-feeding capabilities.
\end{abstract}

KEY WORDS: Protists $\cdot$ Marine fish $\cdot$ First feeding $\cdot$ Larvae $\cdot$ Cod $\cdot$ Oxyrrhis marina $\cdot$ Nannochloropsis sp. $\cdot$ Survival $\cdot$ Growth

Resale or republication not permitted without written consent of the publisher

\section{INTRODUCTION}

Understanding the factors that contribute to recruitment variability has been at the heart of marine fisheries research since Hjort (1914) first devised the 'critical period hypothesis'. Rates of survival of early life stages of marine fish species are thought to be highly sensitive to variability in prey field characteristics (abundance, composition) and/or hydrographic factors (e.g. water temperature and currents) and even small changes in mortality and growth rates of early life stages can cause order-of-magnitude differences in year-class success (Houde 2008). A particularly vulner- able period during early life is the transition from endogenous to exogenous feeding, as larvae need to successfully initiate feeding before they cross the 'point of no return' $\left(P N R_{\text {; }}\right.$ sensu Blaxter \& Hempel 1963). Clearly, it is important to understand the processes influencing temporal and spatial match-mismatch dynamics between larvae and suitable prey (both in terms of prey size and quality) since these processes govern the probability of successful first feeding and early survival of larval fish (Cushing 1975, Yúfera \& Darias 2007, Houde 2008).

It has long been believed that larval marine fish are part of a linear food chain where autotrophic phyto- 
plankton is fed on by heterotrophic zooplankton that, in turn, is preyed upon by fish larvae. Analyses of larval fish gut contents and feeding behaviour has resulted in the claim that herbivorous, crustacean zooplankton (copepods) is the preferred prey of young marine fish larvae (Munk 1997, Pepin \& Penney 2000). However, recently there has been some evidence to suggest a potential flexibility in the feeding behaviour of fish larvae (Pepin \& Dower 2007). In particular, more focus has been given to representatives of the planktonic microbial loop. For example, marine fish larvae have been reported to directly feed on heterotrophic protists (Lasker 1975, Scura \& Jerde 1977, Fukami et al. 1999), organisms that can be highly abundant in marine environments during specific time periods (Tamigneaux et al. 1997, Hansen \& Jensen 2000, Sommer et al. 2002, Ptacnik 2003). However, it is still largely unknown if indirect (incidental) or direct ingestion of algae and heterotrophic protists provides any nutritional and/or energetic value for marine fish larvae.

Evidence exists from marine fish larviculture that microalgae can increase the survival and condition of young, first-feeding larvae; hence 'green water' techniques have been utilised in rearing protocols for decades (Howell 1979, Skiftesvik et al. 2003). For example, yolk-sac Atlantic cod Gadus morhua L. larvae have been reported to ingest phytoplankton either passively or through active filter feeding prior to 'first feeding' on copepod nauplii (Ellertsen et al. 1980, van der Meeren 1991). Changes in the lipid composition that occurred in first-feeding cod larvae reared in the presence of microalgae (van der Meeren et al. 2007) were thought to provide nutritional benefits that delayed the onset of fasting symptoms in unfed larvae such as gut epithelia degeneration, hepatocyte degeneration and cholestasis (Kjørsvik et al. 1991, Diaz et al. 1998, Maurizi 2000). Thus, ingestion of autotrophic phytoplankton (and perhaps the heterotrophic protists that feed on those algae) may represent an alternative (nutritional) pathway that increases starvation resistance and the probability of survival in marine fish larvae in variable feeding environments.

The present laboratory study was designed to answer 2 questions. First, is first-feeding success of marine fish larvae (in this case Baltic cod larvae) on metazooplankton increased when larvae have been reared in the presence of autotrophic phytoplankton (Nannochloropsis sp.) and/or a heterotrophic dinoflagellate (Oxyrrhis marina)? Second, do larvae receive direct nutritional benefits from these microbial loop components as assessed via early growth? Answering these 2 questions will help assess the potential role played by algae and heterotrophic protists in the early feeding, survival and growth of marine fish larvae.

\section{MATERIALS AND METHODS}

Production of yolk-sac larvae. The larvae used in the experiment were hatched from eggs collected from captive Eastern Baltic broodstock cod collected

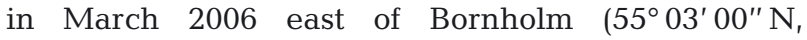
$\left.15^{\circ} 11^{\prime} 50^{\prime \prime} \mathrm{E}\right)$. The egg batch was collected on 16 May 2008 from spontaneous group spawning within the broodstock tank. A total of $600 \mathrm{ml}$ of eggs (90\% fertilisation) was gently collected from the water surface via a PVC pipe into a $500 \mu \mathrm{m}$ mesh bag. The eggs were subsequently disinfected using $400 \mathrm{mg} \mathrm{l}^{-1}$ glutaraldehyde solution for $10 \mathrm{~min}$ before being transferred to a 1001 cylindrical, black, PVC tank, where they were incubated within a recirculation system at $7^{\circ} \mathrm{C}$ and a salinity of 16.0 using artificial salt water (Tropic Marin ${ }^{\circledR}$ ). The surface light intensity was maintained at 15 lux (DVM1300, Velleman $\left.{ }^{\circledR}\right)$. The natural light regime occurring at the time of spawning was used (15h dark: 9h light). Only eggs hatching within a $24 \mathrm{~h}$ period (between 84 and 93 degree-days after collection) were used in experiments. These larvae were maintained for an additional $24 \mathrm{~h}$ prior to the start of the experiment.

Experimental set-up. The experiment was conducted within a controlled-temperature room at $10.0 \pm$ $0.2^{\circ} \mathrm{C}$ (mean \pm range). At 2 days post-hatch (dph), 1200 larvae were transferred to 1 of 3 black, square, 601 holding tanks, representing 3 treatment groups. Each tank was filled with artificial salt water $(0.1 \mu \mathrm{m}$ filtered, salinity 16.0). Larvae were maintained in either salt water ('clear water', CW), in salt water containing the eustigmatophycean Nannochloropsis sp. (NA) $(1.5 \times$

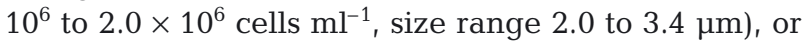
in a tank containing both Nannochloropsis sp. and the heterotrophic dinoflagellate Oxyrrhis marina Dujardin (NO) (1000 cells $\mathrm{ml}^{-1}$, size range 13.3 to $\left.16.0 \mu \mathrm{m}\right)$. The concentration of these organisms in larval tanks was monitored during the experimental period. Nannochloropsis sp. was maintained at the same concentrations in both the NO and NA treatments; decreased concentrations due to feeding by $O$. marina were offset by supplemental additions of Nannochloropsis sp. Gentle aeration (4 $\mathrm{mm}$ diameter glass capillaries, individual air bubbles) was applied to maintain steady water circulation and high oxygen concentrations (>10 $\mathrm{mg} \mathrm{l}^{-1}$ ). All tanks received constant $(24 \mathrm{~h})$ light. The NO and NA treatments were maintained at constant light at $\sim 400$ lux (underwater reading of 180 lux), to ensure sufficient light energy for Nannochloropsis sp. to maintain positive growth rates. A lower surface light intensity (10 lux, 5 lux underwater reading) was used in the CW treatment to account for the higher light penetration in that tank due to the absence of algae. 
At 2 dph, 1200 larvae were randomly loaded into each of the holding tanks ( 1 holding tank treatment ${ }^{-1}$ ). For each of the 3 treatment holding tanks, triplicate 51 plastic aquaria (each containing $4 \mathrm{l}$ salt water) were allowed to acclimatise to experimental conditions $14 \mathrm{~h}$ before the daily experimentation began. The experimental tanks contained the same algal and light conditions as in the associated holding tanks. The experimental tanks remained static, with no air supplementation. The entire experiment was conducted at $10 \pm 0.2^{\circ} \mathrm{C}$. In order to maintain these temperature conditions, holding tanks and experimental tanks were placed in temperature-controlled water baths. The temperature was controlled by computer (Aqua Medic, $\mathrm{T}$ Computer) and monitored throughout the experiment (TLog64-USB, Hygrosens; resolution $0.06^{\circ} \mathrm{C}$ ). The salinity was $16.0 \pm 0.1$ measured at the beginning and end of the experiment (WTW cond315i).

Prey used in daily feeding trials were $2 \mathrm{~d}$ old nauplii of the calanoid copepod Acartia tonsa that had been fed the cryptophycean Rhodomonas baltica Karsten (mean cell size: $7.6 \mu \mathrm{m}$ ). Both $A$. tonsa and $R$. baltica were from cultured strains produced by DTU Aqua (Technical University of Denmark) and reared according to methods reported by Peck \& Holste (2006). The red algal pigment in the guts of the otherwise transparent copepod nauplii acted as a natural marker and aided in the detection of nauplii in the guts of feeding larval cod. To ensure food was non-limiting, concentrations of 1 nauplii $\mathrm{ml}^{-1}$ were employed.

The experiment was conducted for $9 \mathrm{~d}$, through the $P N R$ and after the exhaustion of yolk-sac reserves. Starting at $2 \mathrm{dph}, 60$ larvae were removed each day from each holding tank and 20 larvae were placed into each of 3 experimental tanks. Food items were added to the experimental tanks prior to larval loading. The larvae were then allowed to feed for $4 \mathrm{~h} \pm$ $10 \mathrm{~min}$, after which most of the water was removed and the tanks were placed on ice to chill the remaining water $(\sim 1$ l) and larvae to a low temperature to greatly minimise any further digestion and/or feeding. Each larva was viewed under a dissecting microscope $(50 \times)$ for the presence of food (both Acartia tonsa and algae) in the gut and subsequently digitally photographed at $12 \times$ magnification (Leica DFC). Ten of these larvae were rinsed with distilled water to remove excess salt, placed in $1.5 \mathrm{ml}$ micro-centrifuge vials and stored at $-80^{\circ} \mathrm{C}$ (ultra freezer) until further processing. Any mortalities and deformed or moribund fish were noted. Mortality was noted as a lack of heartbeat. On the day of $50 \%$ hatching ( $0 \mathrm{dph}), 20$ additional larvae were photographed and stored for dry mass analysis.

Measurements. The standard length $(S L, \pm 0.1 \mathrm{~mm})$, myotome height $\left(M H_{1} \pm 0.1 \mathrm{~mm}\right)$ and yolk-sac area
$\left(Y S A, \pm 0.01 \mathrm{~mm}^{2}\right)$ of each larva was measured using image analysis software (Image J, version $1.40 \mathrm{~g}$, freeware, Wayne Rasband, NIH, USA). Myotome height was used as a proxy for condition, reflecting energy allocation to body mass rather than axial length. The larvae were freeze-dried (Christ-Alpha, 16 h, 0.2 millibars) and their freeze-dried mass $\left(D M_{1} \pm 0.1 \mu \mathrm{g}\right)$ was measured using a digital microbalance (Sartorius 1773 MP8).

In larvae with food in the gut, the magnitude of feeding was assessed using a simple gut fullness index (GFI; van der Meeren et al. 2007) that employed scores of 1 ( $<6$ intact copepods and/or remnants in the gut), 2 ( $>6$ clearly distinguished copepods in the gut but a gut that was not distended) or 3 (fully distended gut packed with prey). For each replicate tank, GFI was calculated using the formula:

$$
G F I=\left(N_{1}+2 N_{2}+3 N_{3}\right) \times\left(N_{1}+N_{2}+N_{3}\right)^{-1}
$$

where $N_{1}$ to $N_{3}$ represent the number of larvae with gut fullness scores 1 to 3 , respectively. A mean GFI score for each treatment was calculated based upon the mean scores from each of the 3 replicate tanks.

Data analysis. The mean $( \pm \mathrm{SD})$ incidence of first feeding $(F I)$ was calculated for each treatment on each day based on the percentages of larvae containing food in the gut in each of the 3 replicate tanks. These treatment mean values ( $\mathrm{n}=3$ tanks) were the unit of measure used for all statistical analyses. A 3-parameter log-normal regression was fitted to the data for each treatment:

$$
F I=F I_{\mathrm{MAX}} \cdot \mathrm{e}^{-0.5 \cdot\left(\frac{\ln \left(\frac{\text { age }}{t_{F I \mathrm{MAX}}}\right)}{b}\right)^{2}}
$$

where $F I_{\text {MAX }}$ is a parameter estimating maximum feeding incidence, age = larval age in dph, $t_{F I M A X}$ is a parameter representing the age at maximum mean FI, and $b$ is a constant. Although data were collected on a daily basis, using this regression allowed us to more clearly estimate the point of first feeding, $F I_{50}$ (the larval age when $50 \%$ of the larvae had food in the gut), the larval age and percentage of maximum incidence of feeding $\left(F I_{\text {MAX }}\right)$ and the larval age at the PNR (the larval age when the incidence of first feeding had reduced to $\leq 50 \%, P N R_{50}$ ). The window of opportunity (WOO, the timeframe in which feeding incidence was $>50 \%$ ) could be calculated as $P N R_{50}-F I_{50}$. In addition to this, the magnitude of feeding during the WOO could also be estimated (based on the integral of the curve above $F I_{50}$ ).

Mean larval FI (\%, arcsine-transformed), $S L$ (mm), $D M(\mu \mathrm{g}), M H(\mathrm{~mm}), Y S A\left(\mathrm{~mm}^{2}\right)$ and $G F I$ were compared among treatments $\left(\mathrm{n}=3\right.$ tanks treatment $\left.{ }^{-1}\right)$ on each day of sampling using a 1-way ANOVA followed 
by pair-wise comparisons using a Tukey test (Sigma Stat, version 2.0, SPSS).

\section{RESULTS}

\section{Incidence of first feeding}

Feeding occurred at a younger age in the NA and NO treatments compared to the CW treatment (Fig. 1). Successful first feeding ( $>50 \%$ mean $F I$ ) was initiated by larvae at an age of $4 \mathrm{dph}$ in NA and NO treatments compared to $6 \mathrm{dph}$ for larvae in the CW treatment (calculated $F I_{50}=3.96,3.37$ and $5.57 \mathrm{dph}$ for NA, NO and $\mathrm{CW}$, respectively; Table 1 ). The point of maximum feeding $\left(F I_{\text {MAX }}\right)$, as calculated by nonlinear regression, was reached 1.0 and $1.3 \mathrm{~d}$ earlier in larvae from NA and NO treatments compared to larvae from the CW treatment. However, there was no difference in the $P N R_{50}(8.2,8.3$ and $8.9 \mathrm{~d}$ for larvae in CW, NA and NO treatments, respectively). Therefore, precocious exogenous feeding by NA and NO larvae extended their WOO compared to CW larvae. The mean magnitude of first feeding (within the $4 \mathrm{~h}$ measurement period) by yolk-sac larvae in NA and NO treatments was respectively 1.4 and 2.4 times greater than that observed for larvae in the CW treatment.

\section{Gut fullness}

The addition of algae in the water increased larval gut fullness (Fig. 2). The cod larvae in NA and NO treatments exhibited a high GFI at 3 to $10 \mathrm{dph}$ compared to CW larvae, which were moderate feeders (significant difference at 4, 5, 7 and 9 dph; Fig. 2D). Overall, there was no significant difference in GFI between NA and NO treatments except at $10 \mathrm{dph}$, when the index of the latter was greater than the former.

\section{Growth and development}

Larval $S L$ increased from 4.4 to $4.6 \mathrm{~mm}$ by $5 \mathrm{dph}$ and then remained more or less unchanged, whereas $D M$ steadily decreased from 68.7 to 27.9 to $28.9 \mu \mathrm{g}$ from the start until the end of the experiment (Fig. 3). Yolk-sac area also decreased throughout the experiment (from 1.39 to $0.015-0.027 \mathrm{~mm}^{2}$ ) and yolk absorption rates, as calculated from exponential regression lines, were $-0.451,-0.442$ and $-0.441 \mathrm{~d}^{-1}$ in the NO, NA and CW treatments, respectively. Myotome heights were between 0.21 and $0.24 \mathrm{~mm}$ and changed little throughout the experiment. For each of these 4 measures $(S L, D M$, YSA and $M H$ ), the vast majority of daily treatment

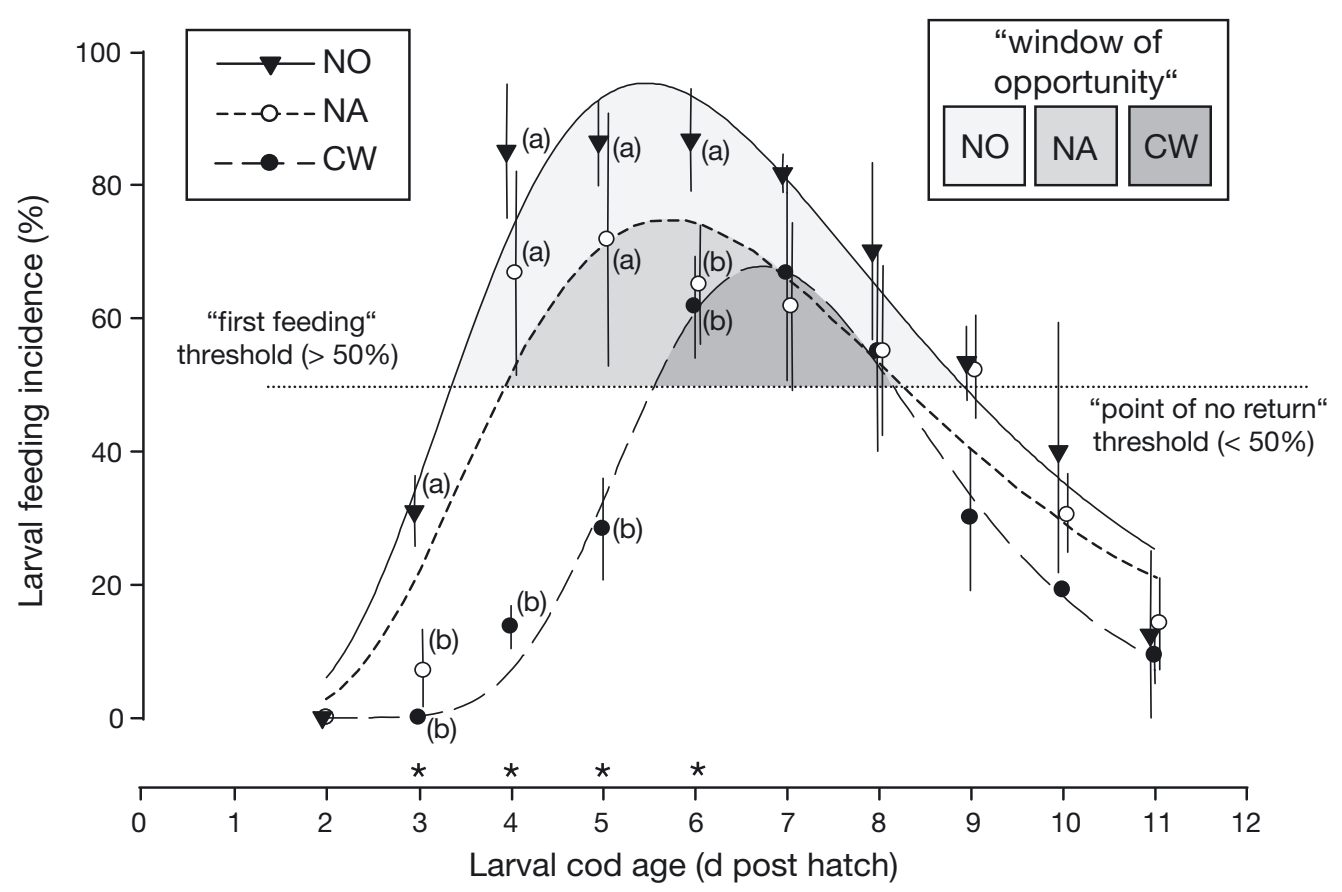

Fig. 1. Mean feeding incidence $(F I)$ in yolk-sac larvae versus larval age in the presence (NA) or absence (CW) of algae (Nannochloropsis sp.) or in the presence of algae and Oxyrrhis marina (NO). Significant differences in FI were found among treatments at ages 3 to $6 \mathrm{~d}$ post-hatch. *Days with significant differences among treatment values. Different letters ( $\mathrm{a}$, b) denote significant differences (ANOVA, Tukey post hoc test, $\mathrm{p} \leq 0.05, \mathrm{n}=3$ replicates treatment ${ }^{-1}$ ). The 'window of opportunity' and magnitude of $F I$ are also indicated (shaded areas) calculated from regression equations (Eq. 2 in 'Data analysis' under 'Materials and methods'; see Table 1). Error bars indicate SD $(n=3)$ 
Table 1. Summary information for feeding incidence (FI) by yolk-sac cod larvae reared at $10^{\circ} \mathrm{C}$ in only seawater (clear water, CW) and in seawater including Nannochloropsis sp. (NA) and both Nannochloropsis sp. and Oxyrrhis marina (NO). Parameter estimates and statistics for Eq. (2) (see 'Data analysis' under 'Materials and methods') are provided: maximum mean feeding incidence $\left(F I_{\text {MAX }}\right)$, slope $(b)$ and age of larvae at $F I_{\text {MAX }}$. Calculated values include the age of larvae at $50 \%$ feeding incidence $\left(t_{50}\right)$, the point of no return $\left(P N R_{50}\right)$, window of opportunity (WOO) and the relative magnitude of feeding (see Fig. 1). FI was expressed as the mean of 3 replicate tanks. dph: days post-hatch

\begin{tabular}{|c|c|c|c|}
\hline \multirow{2}{*}{ Estimates } & \multicolumn{3}{|c|}{ - Treatment } \\
\hline & $\mathrm{CW}$ & NA & NO \\
\hline \multicolumn{4}{|l|}{ FI parameter estimates (Eq. 2) } \\
\hline$F I_{\text {MAX }}(\%)$ & $67.72 \pm 2.43$ & $74.62 \pm 6.40$ & $95.13 \pm 5.36$ \\
\hline$b$ & $0.24 \pm 0.01$ & $0.41 \pm 0.05$ & $0.43 \pm 0.03$ \\
\hline$t_{F I \text { MAX }}\left(\right.$ age at $\left.F I_{\text {MAX }}\right)(\mathrm{dph})$ & $6.73 \pm 0.07$ & $5.71 \pm 0.24$ & $5.48 \pm 0.16$ \\
\hline \multicolumn{4}{|l|}{ Statistics (Eq. 2) } \\
\hline Observations (n) & 10 & 10 & 10 \\
\hline Adjusted $r^{2}$ & 0.91 & 0.85 & 0.93 \\
\hline $\mathrm{p}$ & $<0.01$ & $<0.01$ & $<0.01$ \\
\hline \multicolumn{4}{|c|}{ Calculated first-feeding estimates } \\
\hline$t_{50}$ (first age at $\left.F I_{50}\right)(\mathrm{dph})$ & 5.57 & 3.96 & 3.37 \\
\hline$P N R_{50}(\mathrm{dph})$ & 8.15 & 8.26 & 8.91 \\
\hline$W O O\left(P N R_{50}-F I_{50}\right)(\mathrm{dph})$ & 2.58 & 4.3 & 5.54 \\
\hline Relative feeding magnitude ${ }^{a}$ & 1.0 & 1.4 & 2.4 \\
\hline
\end{tabular}

comparisons was not significantly different except in 4 instances: (1) $S L$ at $10 \mathrm{dph}$ (NA > CW), (2) DM at $10 \mathrm{dph}$ (CW > NO and NA), (3) YSA at $4 \mathrm{dph}$ (NA > NO

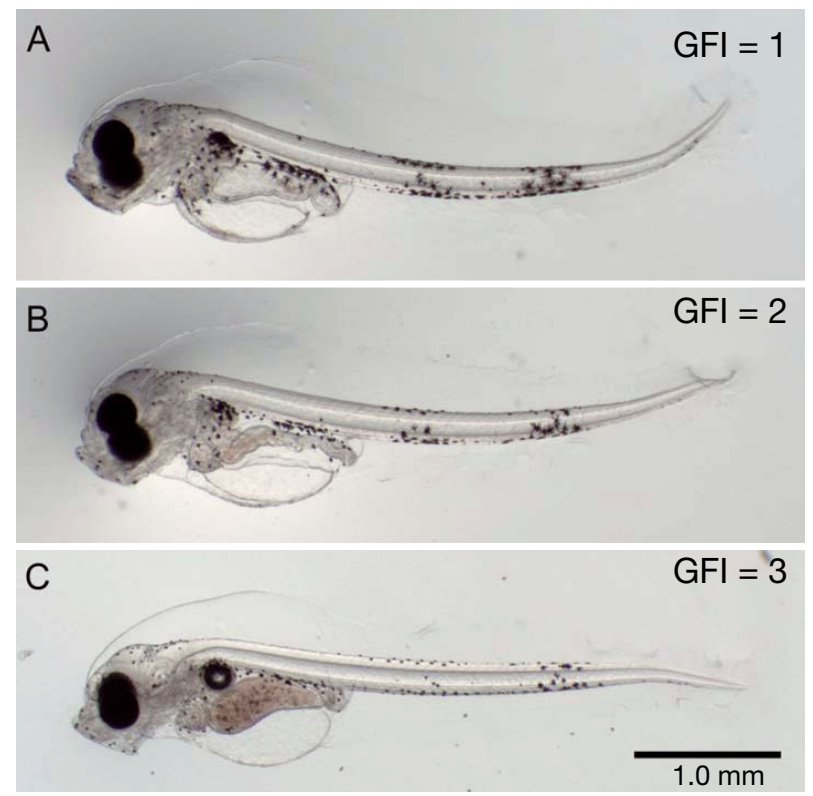

and $\mathrm{CW}$ ) and (4) $\mathrm{MH}$ at $9 \mathrm{dph}(\mathrm{CW}>$ NO and NA).

\section{DISCUSSION}

The present study clearly demonstrated precocious and more intense exogenous feeding by the larvae of a marine fish species in the presence of autotrophic phytoplankton (Nannochloropsis sp.) and heterotrophic dinoflagellates (Oxyrrhis marina). Young larvae in our CW, NA and NO treatments started first feeding at 6, 4 and 3 dph, had 11, 42 and $60 \%$ yolk reserves remaining on that day, and reached a peak of 68,75 and $95 \%$ first feeding on 7, 6 and $5 \mathrm{dph}$, respectively. The presence of autotrophic phytoplankton and heterotrophic protists, therefore, corresponded to a substantial increase in first-feeding success and expansion of the WOO for first feeding. Despite these benefits, our experiment also revealed that the nutritional value of these protists was not great enough to alter the (macroscopic) growth characteristics of yolk-sac larvae relative to conspecifics maintained in pure salt water.

Fig. 2. (A-C) Example of gut fullness index (GFI) scores in first-feeding larvae, as typed either ' 1 ' $(<6$ intact copepods and/or remnants in the gut), '2' (>6 clearly distinguished copepods in the gut but a gut that was not distended) or ' 3 ' (fully distended gut, packed with prey). Photos taken at $12 \times$ magnification. (D) Mean GFI scores in yolk-sac larvae versus age for larvae reared in the presence (NA) or absence (CW) of algae (Nannochloropsis sp.) or in the presence of algae and Oxyrrhis marina (NO). On a given sampling day, significant differences in mean GFI are indicated with different letters (ANOVA, Tukey post hoc test, $\mathrm{p}<0.05$ ).

No significant differences among treatments were found at 3, 8 and $11 \mathrm{~d}$ post-hatch. Error bars indicate SD (n = 3 tanks) 


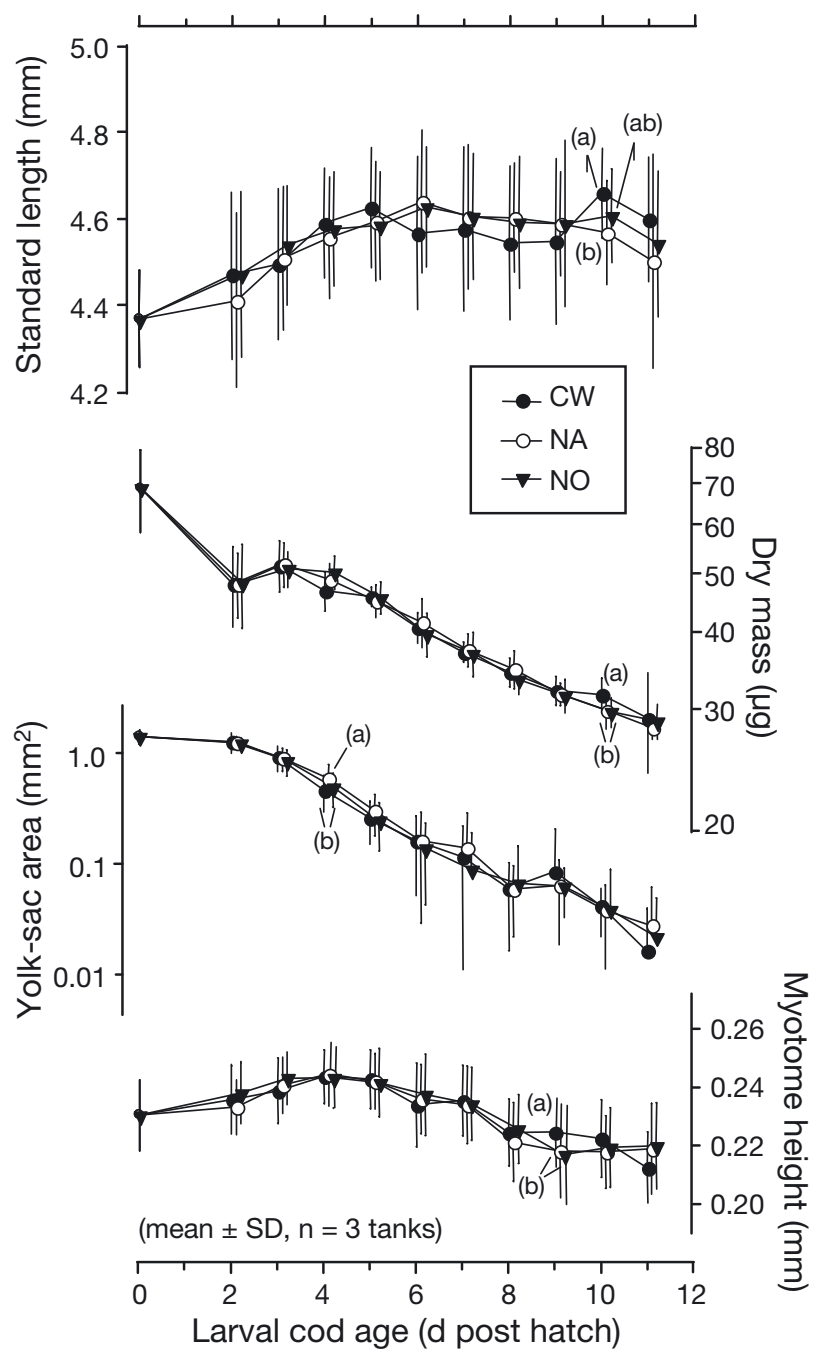

Fig. 3. Mean standard length, freeze-dried mass, yolk-sac area and myotome height versus age for yolk-sac larval cod reared in the presence (NA) or absence (CW) of algae (Nannochloropsis sp.) or in the presence of algae and Oxyrrhis marina (NO). On a given sampling day, different letters denote significant differences (ANOVA, Tukey post hoc test, $\mathrm{p}<0.05$, $\mathrm{n}=3$ replicate tanks treatment $\left.^{-1}\right)$. Error bars indicate SD $(\mathrm{n}=3)$

The results of the present study agree well with those of previous research reporting beneficial effects of rearing marine fish larvae in the presence of microalgae including (1) earlier first feeding (Kentouri 1985, Naas et al. 1992, Maurizi 2000), (2) reduction of metabolic stress and prolonged survival of unfed larvae (reviewed in Muller-Feuga et al. 2003) and (3) dramatic improvement of early survival in marine fish species considered problematic to rear (Naas et al. 1992, Reitan et al. 1997). After first feeding, the presence of algae may also (4) increase rates of food consumption and/or growth (Øie et al. 1997, Bengtson et al. 1999, van der Meeren et al. 2007). Previous work by van der Meeren et al. (2007) indicated increased gut filling at $3 \mathrm{dph}\left(7\right.$ to $\left.8^{\circ} \mathrm{C}\right)$ in cod larvae exposed to microalgae, which agrees with the results obtained in the present study. However, the present study indicates that this improved gut filling is sustained throughout the mixed feeding stage until $P N R$ is reached. The mechanism responsible for our GFI findings is not known but could involve either intrinsic and/or extrinsic (environmental) factors. For example, different combinations of light intensity and algal concentration may enhance visual contrast, improving prey capture in larval fish (Boehlert \& Morgan 1985, Naas et al. 1992). It is important to note that the differences in feeding intensity observed among treatments in the present study cannot be attributed to the small differences in light intensity (175 lux) experienced by larvae in CW compared to NA and NO groups. No significant differences in first feeding by cod larvae were observed over a larger range in light intensities ( $\sim 50$ to 690 lux) in the presence or absence of microalgae (van der Meeren et al. 2007). The difference in feeding intensity between our NA and NO groups (which were at the same light and algal densities) supports the overriding effect of algal characteristics over light intensity in this particular study.

This stimulation of early feeding could be linked to the drinking phase, an important preliminary phase that maintains osmotic balance in the developing larvae as well as instigating absorption of dissolved organic material and ingestion of some small particulate matter (Muller-Feuga et al. 2003). During the drinking phase, cod have been reported to ingest dinoflagellates either passively (via drinking) or actively (by filter feeding) (Ellertsen et al. 1980, van der Meeren 1991), and evidence of some nutritional benefit from imbibing algae has been observed, including changes in phospholipid composition and triglycerol content in first-feeding larval cod attributed to the presence of microalgae (Isochrysis sp.) (van der Meeren et al. 2007). After first feeding, cod larvae have been shown to feed on small protozoans but this appears to be more energetically costly compared to feeding on larger copepod nauplii (Hunt von Herbing et al. 2001). Thus, our finding of no direct (macroscopic) nutritional benefit, such as decreased yolk/energy utilisation or improvement in larval condition indices (dry mass- and myotome heightat-age) among larvae in any feeding treatment, may not be surprising. Regardless of a lack of direct growth benefits, stimulation of first feeding by microalgae and heterotrophic protists may be particularly important for the survival of cod and perhaps in other marine fish species that have a relatively brief WOO. Larvae in the $\mathrm{CW}$ treatment started to first-feed (reached $F I_{50}$ ) at 60 degree-days post-hatch $\left(\mathrm{ddph}={ }^{\circ} \mathrm{C} \cdot \mathrm{dph}\right)$, and at 63 ddph, unfed cod larvae exhibited morphological changes in gut villi detrimental to digestive and absorp- 
tive capacity (Kjørsvik et al. 1991). Furthermore, the earlier feeding and increased GFI when feeding would have likely caused NO and NA larvae to exhibit more rapid growth compared to CW larvae after first feeding, but this was not tested in the present study.

Although direct nutritional benefits of algae and heterotrophic protists to larvae were lacking in the present study, their presence appeared to 'prime' biochemical and/or developmental systems that, in turn, promoted first feeding. During early development, larval fish cannot synthesise phospholipids (Bell et al. 2003) and must acquire these through their diet. Algae have been demonstrated to stimulate the production of digestive enzymes such as amylase and trypsin, characteristically the first enzymes to be recorded in early marine fish ontogeny (Cahu et al. 1998). It was hypothesised by Cahu et al. (1998) and other authors (Støttrup 1994) that the large amounts of free amino acids contained in algae could be responsible for the observed stimulation in the production of trypsin. In the wild, free amino acids are often at concentrations $<10^{-7} \mathrm{M}$ (Braven et al. 1984) but can occur at higher concentrations in areas of high phytoplankton production (Williams \& Poulet 1986). Therefore, intuitively, one could link these dissolved free amino acids to the stimulation of feeding of fish larvae in the wild. This seems reasonable since concentrations of algae and protists used in the present laboratory study were of the same magnitude as those occurring in situ (e.g. Arndt 1991, Tamigneaux et al. 1997, Hansen \& Jensen 2000) at the locations and during times of the year when first-feeding cod larvae would be expected to occur. Naturally, other benefits from microalgae and protozooplankton such as improvement in larval microbial gut flora (Skjermo \& Vadstein 1993) should not be dismissed.

The results of the present study highlight the need to revisit the importance of autotrophic phytoplankton and heterotrophic protists in the early survival and growth of marine fish larvae. Previous studies indicated that the larvae of some marine fish species routinely ingest phytoplankton (e.g. Northern anchovy Engraulis mordax feeding on dinoflagellates) which appeared to offer some nutritional benefit (e.g. Scura \& Jerde 1977) and was thought to be important for early survival and recruitment success (Lasker 1975). Our results clearly indicated that cod obtained no nutritional (growth) benefit from ingesting algae and heterotrophic protists (protozooplankton) prior to first feeding. However, the presence of adequate amounts of protozooplankton may be critical to the survival and growth of cod by acting to prime first-feeding capabilities of this species, altering the window of opportunity for successful firstfeed and, in turn, influencing the match-mismatch dynamics between first-feeding cod and their macrozooplankton prey.

\section{LITERATURE CITED}

Arndt H (1991) On the importance of planktonic protozoans in the eutrophication process of the Baltic Sea. Int Rev Gesamten Hydrobiol Hydrogr 76:387-396

Bell JG, McEvoy LA, Estevez A, Shields RJ, Sargent JR (2003) Optimising lipid nutrition in first-feeding flatfish larvae. Aquaculture 227:211-220

Bengtson DA, Lydon L, Ainley JD (1999) Green-water rearing and delayed weaning improve growth and survival of summer flounder. N Am J Aquac 61:239-242

Blaxter JHS, Hempel G (1963) The influence of egg size on herring larvae (Clupea harengus L.). J Cons Int Explor Mer 28:211-240

Boehlert GW, Morgan JB (1985) Turbidity enhances feeding abilities of larval Pacific herring, Clupea harengus pallasi. Hydrobiologia 123:161-170

Braven J, Evens R, Butler EI (1984) Amino acids in sea water. Chem Ecol 2:11-21

> Cahu CL, Zambonino Infante JL, Peres A, Quazuguel P, Le Gall MM (1998) Algal addition in sea bass (Dicentrarchus labrax) larvae rearing: effect on digestive enzymes. Aquaculture 161:479-489

Cushing DH (1975) Marine ecology and fisheries, Vol 1. Cambridge University Press, Cambridge

Diaz JP, Mani-Ponset L, Guyot E, Connes R (1998) Hepatic cholestasis during the post-embryonic development of fish larvae. J Exp Zool 280:277-287

Ellertsen B, Solemdal P, Stroemme T, Tilseth S, Westgaard T, Moksness E, Oeiestad V (1980) Some biological aspects of cod larvae (Gadus morhua L.). Fiskeridir Skr Ser Havunders 17:29-47

Fukami K, Watanabe A, Fujita S, Yamaoka K, Nishijima T (1999) Predation on naked protozoan microzooplankton by fish larvae. Mar Ecol Prog Ser 185:285-291

Hansen BW, Jensen F (2000) Specific growth rates of protozooplankton in the marginal ice zone of the central Barents Sea during spring. J Mar Biol Assoc UK 80:37-44

Hjort J (1914) Fluctuations in the great fisheries of northern Europe viewed in the light of biological research. Rapp p-v Reun Cons Int Explor Mer 20:1-228

Houde ED (2008) Emerging from Hjort's shadow. J Northwest Atl Fish Sci 41:53-70

Howell BR (1979) Experiments on the rearing of larval turbot, Scophthalmus maximus L. Aquaculture 18:215-225

Hunt von Herbing I, Gallager SM, Halteman W (2001) Metabolic costs of pursuit and attack in early larval Atlantic cod. Mar Ecol Prog Ser 216:201-212

Kentouri M (1985) Comportement larvaire de 4 sparides méditerranéens en élevage: Sparus aurata, Diplodus sargus, Lithognathus mormyrus, Puntazzo puntazzo (poissons téléostéens). $\mathrm{PhD}$ dissertation, Université des Sciences et Techniques du Languedoc, Université Montpellier II

Kjørsvik E, van der Meeren T, Kryvi H, Arnfinnson J, Kvenseth PG (1991) Early development of the digestive tract of cod larvae, Gadus morhua L., during start-feeding and starvation. J Fish Biol 38:1-15

Lasker R (1975) Field criteria for survival of anchovy larvae: the relation between inshore chlorophyll maximum layers and successful first feeding. Fish Bull 73:453-462

Maurizi A (2000) Modifications expérimentales des conditions trophiques au début de la vie larvaire chez la daurade Sparus aurata. PhD dissertation, Université de Montpellier II

Muller-Feuga A, Robert R, Cahu C, Robin J, Divanach P (2003) Uses of microalgae in aquaculture. In: Støttrup JG, 
McEvoy LA (eds) Live feeds in marine aquaculture. WileyBlackwell, p 336

Munk P (1997) Prey size spectra and prey availability of larval and small juvenile cod. J Fish Biol 51:340-351

Naas KE, Næess T, Harboe T (1992) Enhanced first feeding of halibut larvae (Hippoglossus hippoglossus L.) in green water. Aquaculture 105:143-156

Øie G, Makridis P, Inge Reitan K, Olsen Y (1997) Protein and carbon utilization of rotifers (Brachionus plicatilis) in first feeding of turbot larvae (Scophthalmus maximus L.). Aquaculture 153:103-122

Peck MA, Holste L (2006) Effects of salinity, photoperiod and adult stocking density on egg production and hatching success of Acartia tonsa (Calanoida:Copepoda): optimizing intensive cultures. Aquaculture 255:341-350

Pepin P, Dower JF (2007) Variability in the trophic position of larval fish in a coastal pelagic ecosystem based on stable isotope analysis. J Plankton Res 29:727-737

Pepin P, Penney R (2000) Feeding by a larval fish community: impact on zooplankton. Mar Ecol Prog Ser 204:199-212

Ptacnik R (2003) Omnivory in planktonic food webs: a study on the impact of mixotrophic flagellates and microzooplankton on food web dynamics and productivity. PhD dissertation, Christian-Albrechts-Universität, Kiel

Reitan KI, Rainuzzo JR, Øie G, Olsen Y (1997) A review of the nutritional effects of algae in marine fish larvae. Aquaculture 155:207-221

Scura ED, Jerde CW (1977) Various species of phytoplankton as food for larval northern anchovy, Engraulis mordax, and relative nutritional value of the dinoflagellates Gymnodinium spelendens and Gonyaulax polyedra. Fish Bull US 75:577-584

Skiftesvik AB, Browman HI, St-Pierre JF (2003) Life in green water: the effect of microalgae on the behaviour of Atlantic cod (Gadus morhua) larvae. In: Browman HI, Skiftesvik

Editorial responsibility: Hans Heinrich Janssen, Oldendorf/Luhe, Germany
$\mathrm{AB}$ (eds) Big fish bang. Institute of Marine Research, Bergen, p 97-103

Skjermo J, Vadstein O (1993) The effect of microalgae on skin and gut bacterial flora of halibut larvae. In: Reinertsen $\mathrm{H}$, Dahle LA, Jørgensen L, Tvinnerein K (eds) Fish farming technology: Proc 1st Int Conf Fish Farming Technol, Trondheim, 9-12 Aug 1993. A. A. Balkema, Rotterdam, p 61-67

Sommer U, Stibor H, Katechakis A, Sommer F, Hansen T (2002) Pelagic food web configurations at different levels of nutrient richness and their implications for the ratio fish production:primary production. Hydrobiologia 484:11-20

Støttrup JG (1994) The intensive rearing of turbot (Scophthalmus maximus L.) larvae. Nutritional and environmental aspects of larval rearing. $\mathrm{PhD}$ dissertation, University of Southern Denmark, Odense

Tamigneaux E, Mingelbier M, Klein B, Legendre L (1997) Grazing by protists and seasonal changes in the size structure of protozooplankton and phytoplankton in a temperate nearshore environment (western Gulf of St. Lawrence, Canada). Mar Ecol Prog Ser 146:231-247

> van der Meeren T (1991) Algae as first food for cod larvae, Gadus morhua L.: filter feeding or ingestion by accident? J Fish Biol 39:225-237

$>$ van der Meeren T, Mangor-Jensen A, Pickova J (2007) The effect of green water and light intensity on survival, growth and lipid composition in Atlantic cod (Gadus morhua) during intensive larval rearing. Aquaculture 265:206-217

Williams R, Poulet SA (1986) Relationship between the zooplankton, phytoplankton, particulate matter and dissolved free amino acids in the Celtic Sea. 1. Unstratified water conditions. Mar Biol 90:279-284

Yúfera M, Darias MJ (2007) The onset of exogenous feeding in marine fish larvae. Aquaculture 268:53-63

Submitted: August 7, 2009; Accepted: May 11, 2010

Proofs received from author(s): July 5, 2010 